\title{
Evaluating the effect of proposed tariff protection for the South African broiler industry
}

By

Ms P Davids ${ }^{1}$, Prof FH Meyer ${ }^{2}$, Ms M Louw ${ }^{3}$

${ }^{1,3}$ Research Analyst and ${ }^{2}$ Director: Bureau for Food and Agricultural Policy Department of Agricultural Economics, Extension and Rural Development

Faculty of Natural and Agricultural Sciences

University of Pretoria

${ }^{1}$ tracy.davids@up.ac.za_ $\quad{ }^{2}$ ferdi.meyer@up.ac.za ${ }^{3}$ marlene.labuschagne@up.ac.za

The authors wish to acknowledge the financial support from the National Agricultural Marketing Council (NAMC) in the completion of this research. 


\title{
Evaluating the effect of proposed tariff protection for the South African broiler industry
}

\begin{abstract}
Following the application in March 2013 by the South African Poultry Association for increased tariffs to insure the sustainability of South African broiler production, this paper critically evaluates the effect of increased tariffs on broiler producers and chicken meat consumers in South Africa. Arguing beyond the level of tariffs, it highlights some of the deeper underlying drivers of competitiveness in the industry. From a self-sufficiency perspective, the need to support broiler producers is clear, yet the cost to consumers as well as the segment of the population that would have to bear the cost of higher tariffs is questioned. The proposed tariffs, as well as two other possible scenarios are simulated within a partial equilibrium framework in order to determine the effect on the fundamentals of the South African broiler industry. Simulations highlight the difference in outcomes when imports originating from the EU are also included in the general tariff increase. Under the basic scenario that simulates the impact of the current tariff application by SAPA, consumer prices for whole frozen chicken will increase by $2.6 \%$ while producers will enjoy an increase in producer prices of approximately 5\%. On average, local production will increase by 16000 tons per annum in the long run. Although 5\% is a significant margin on the bottom line for broiler producers and a $2 \%$ increase in the average consumer price seems to be digestible, one has to take a step back and ask the question why our chicken producers cannot compete against imported chicken.
\end{abstract}

\section{INTRODUCTION}

Chicken consumption in South Africa has grown rapidly over the past decade. Despite this growth, the broiler industry was recently classified by the South African department of trade and industry (DTI) as an industry in distress, with the South African Poultry Association (SAPA) claiming that rising feed costs, as well as oversupply resulting from an influx of relatively cheaper imports are the main reasons for this distress (SAPA, 2013:2). As such, the International Trade Administration Commission of South Africa (ITAC) has initiated a review of the current tariff structure. This paper seeks to evaluate the effect of such tariff increases, considering both the benefit to producers and the cost to consumers and further argues beyond the level of tariffs, highlighting some of the deeper underlying drivers of competitiveness in the industry.

Agricultural trade protection is a topic that has been researched and discussed at length around the world. Despite many arguments describing the benefits of free trade, protectionism is still widely practiced worldwide, particularly in agriculture. The main arguments for the use of trade protection have been the protection of strategic industries, deterring unfair competition, saving jobs and maintaining an extent of self-sufficiency (Laroche Dupraz \& Postolle, 2011:1; Salvatore, 2007:302-304; Houck, 1986:21-24). 
Chicken dominates the South African meat market and its role of providing a preferable and affordable form of protein to South African consumers would qualify the South African poultry industry as a strategic industry, with a strong contribution towards food security in South Africa. Food security is a pressing topic, not only in South Africa, but also in the rest of the world. In South Africa, the right to access sufficient and affordable food is embedded in the constitution, with the Department of Agriculture, Forestry and Fisheries (DAFF) mandated to develop policies and support programmes that ensure South African citizens are given agricultural opportunities that will enable them to meet their basic food needs. DAFF's major role, amongst others, is to ensure that opportunities are created that encourage South Africans to participate in agriculture, producing food and reducing food insecurity in the country (Du Toit, 2011:1-3).

According to the world food summit, food security exists when all people, at all times, have physical and economic access to sufficient, safe, nutritious food to meet their dietary needs and food preferences for an active lifestyle (FAO, 1996). Access therefore implies not only availability, but also affordability of food. If imported chicken offers a more affordable alternative to domestically produced chicken, protective trade policy will have a negative effect on the affordability of food for the poorest segment of the population. At the same time, if this strategic industry is not able to compete economically, a lack of support may lead to its downfall, leading to a decrease in employment opportunities while also negatively impacting on self-sufficiency. Laroche Duprez and Postolle (2011:1) in fact argue that long term food security cannot rest on dependence of food imports, but should rather be built on the development of domestic production, sheltered from world price fluctuations and unfair competition by appropriate policies.

Strategically, self-sufficiency is an important consideration, as factors beyond national control could influence the constant availability of imported food. In the case of poultry, a disease outbreak in the country of origin could lead to mandatory closure of imports, leaving consumers vulnerable should domestic production not occur. At the same time, macroeconomic variables like exchange rates could cause great volatility in the price of imported food, affecting affordability adversely. Laroche Duprez and Postolle (2011:3), through the concept of 'food sovereignty' promote the idea that developing countries should have the right to protect themselves from food imports when these imports compete with and risk destabilizing local production. At the same time, the cost to the consumer cannot be ignored.

The identification of agriculture as a strategic sector in terms of employment by the national development plan is another worthwhile consideration when protective policy is considered. Though protective policy may increase domestic poultry prices and therefore affect food security of the poorest segment of the SA population, the loss of jobs should the industry remain distressed would be catastrophic. As such, the effect of protective trade policy must be considered on poultry prices, as well as the ability of the domestic industry to create and maintain jobs, both in poultry production, poultry processing and related industries such as maize and soya for poultry feed. The ideal policy framework should consider a balance 
between consumer prices and support of the domestic industry in order to create and maintain employment opportunities.

\section{AN HISTORIC PERSPECTIVE ON THE SOUTH AFRICAN BROILER INDUSTRY}

\subsection{INDUSTRY BACKGROUND}

According to the Department of Agriculture, Forestry and Fisheries (DAFF), the broiler industry was the largest segment of the South African agricultural sector in 2011, contributing $17.85 \%$ (R25,068 billion) to total value of agricultural production (DAFF, 2012:79-80). The sector does not only contribute directly however, as it consumes approximately 30 percent of total maize consumption in South Africa through feed (SAPA, 2011:14).

Broiler producers in South Africa have been under pressure for some time, as feed costs have increased significantly. As a net importer of chicken, the industry is integrated into international markets and prices are therefore expected to follow similar trends to the international market. While feed costs have increased by $157 \%$ from 2001 to 2012, the chicken price has been capped by the increased flow of cheaper imports. During the same period, chicken prices have increased by only $61 \%$, which implies that the only mechanism for remaining economically sustainable was through technological improvement and efficiency gains, as measured by continuous improvements to the productive efficiency factor which considers feed conversion rates, mortality, slaughter weights and slaughter age. As a result of the cost pressures, many smaller producers that do not have integrated feed producers and economies of scale benefits have been unable to stay in production. A comparison between the chicken price and chicken feed costs, both expressed as an index with 2008 as base year is provided in Figure 1.

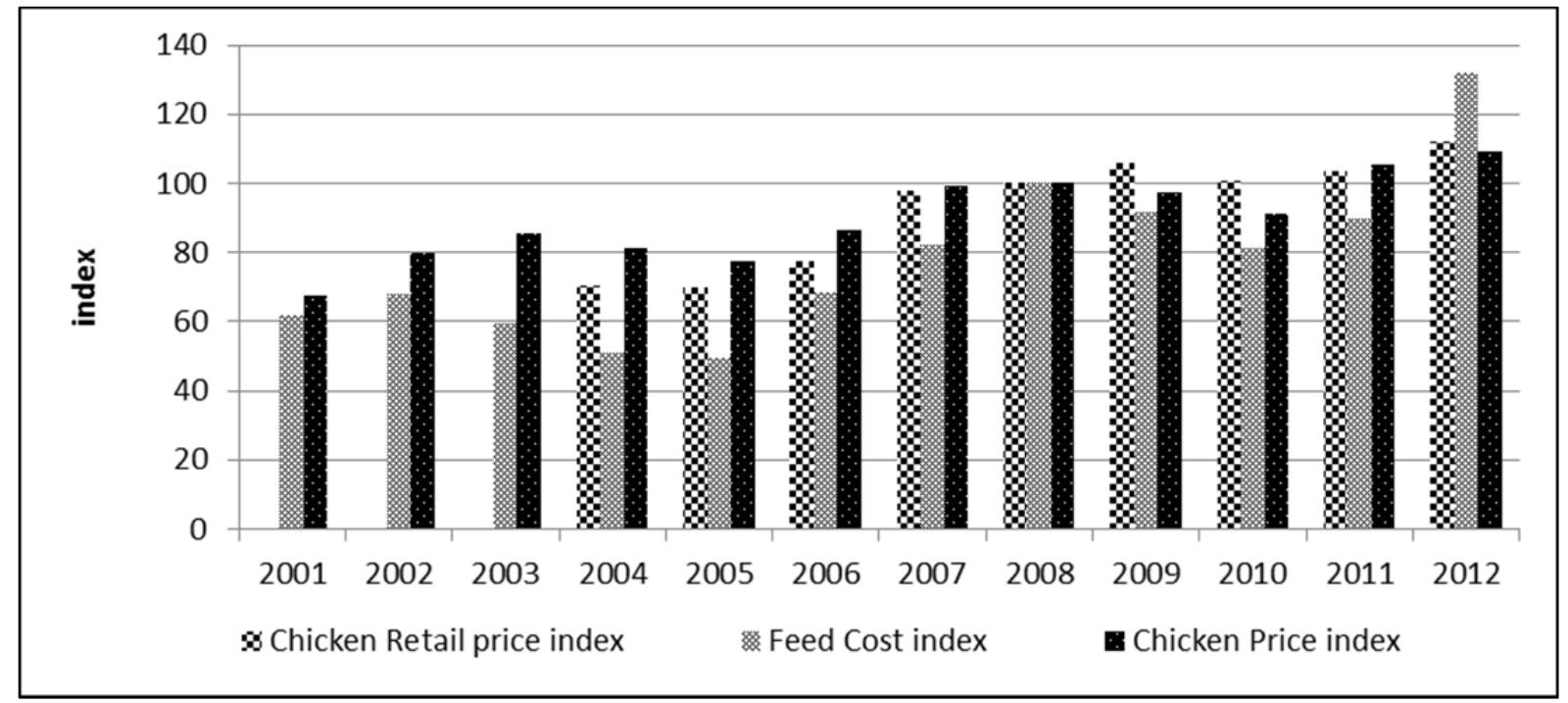

Figure 1: Comparison between chicken prices and chicken feed prices

Source: Statistics South Africa (2012) and South African poultry association (SAPA) (2012) 
Technically, South African broiler producers are very efficient, comparing well with producers in both the United States of America (USA) and Brazil, arguably the most important broiler producing countries in the world. A benchmark of technical efficiency is included in Table 1.

Table 1: Broiler efficiency benchmark: 2011

\begin{tabular}{|l|l|l|l|l|}
\hline & & Brazil & USA & RSA \\
\hline Age & Days & 35 & 35 & 35 \\
\hline Live Weight & $\mathrm{Kg}$ & 1.883 & 1.805 & 1.84 \\
\hline Average daily gain & $\mathrm{g} /$ day & 53.81 & 51.59 & 52.56 \\
\hline Mortality & $\%$ & 3.14 & 2.37 & 4.52 \\
\hline Feed Conversion Ratio & & 1.658 & 1.802 & 1.671 \\
\hline Performance Efficiency Factor & & 314 & 280 & 301 \\
\hline
\end{tabular}

Source: Lovell (2012:45)

Considering the fact that technical efficiency of South African growers is comparable to some of the top broiler producing countries, South African producers should be able to hold their own against competition from South America, yet the import parity price calculated is significantly below the domestic price, suggesting that upon introduction of the costs of production, South African producers no longer compete that well. The comparison of import parity with the domestic price for both frozen whole birds and weighted average net sales value in South Africa is illustrated in Figure 2.

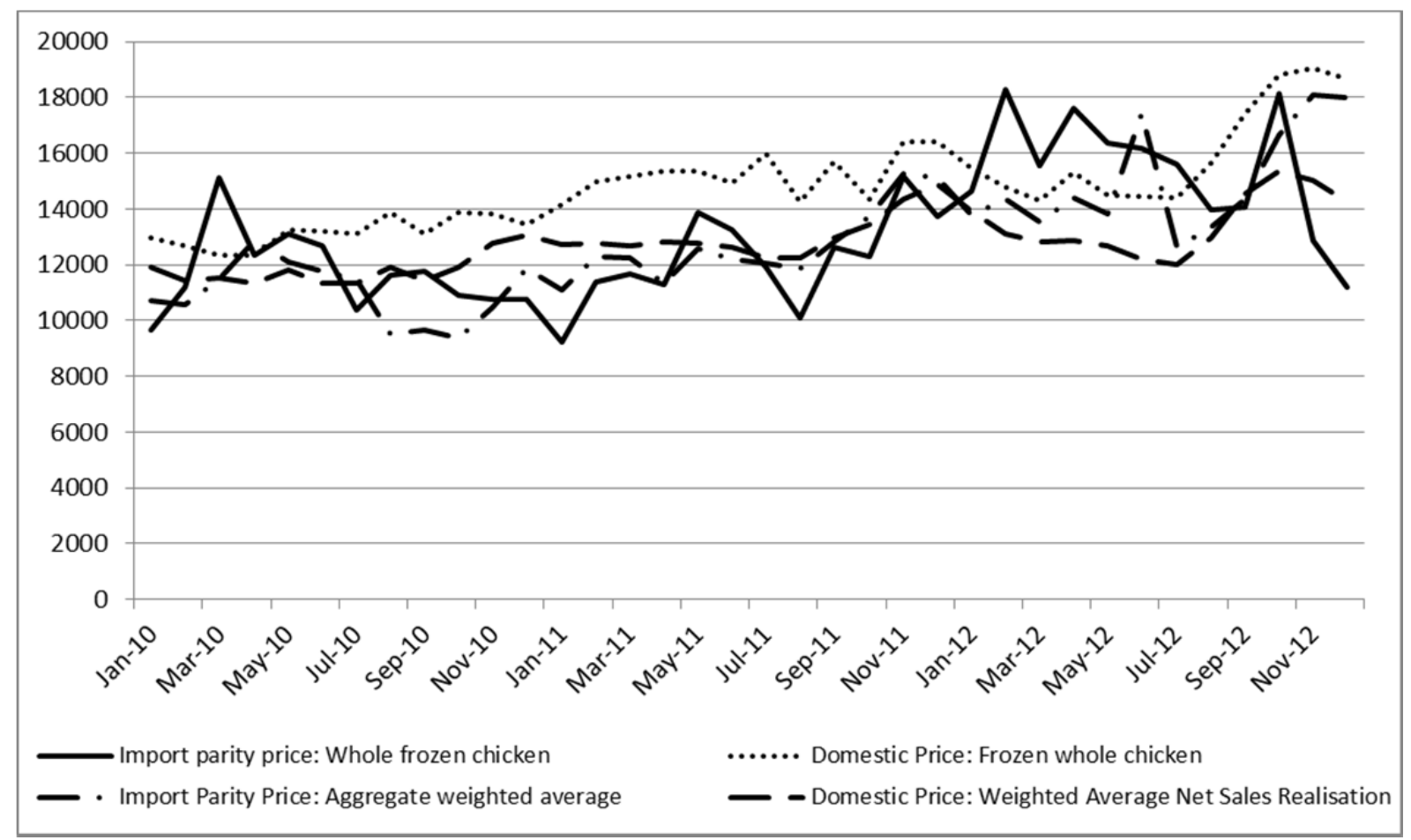

Figure 2: Import parity and domestic price comparison for South Africa

Source: Author compilation 
The United States international trade commission (2012:8.9) in fact states that 'Despite rising feed costs, Brazil and the United States are the most efficient and lowest-cost broiler producers in the world, giving both countries a competitive advantage against producers in third-country markets.' Based on July 2011 data, the average producer cost for Brazil, USA and South Africa is illustrated in Figure 3.

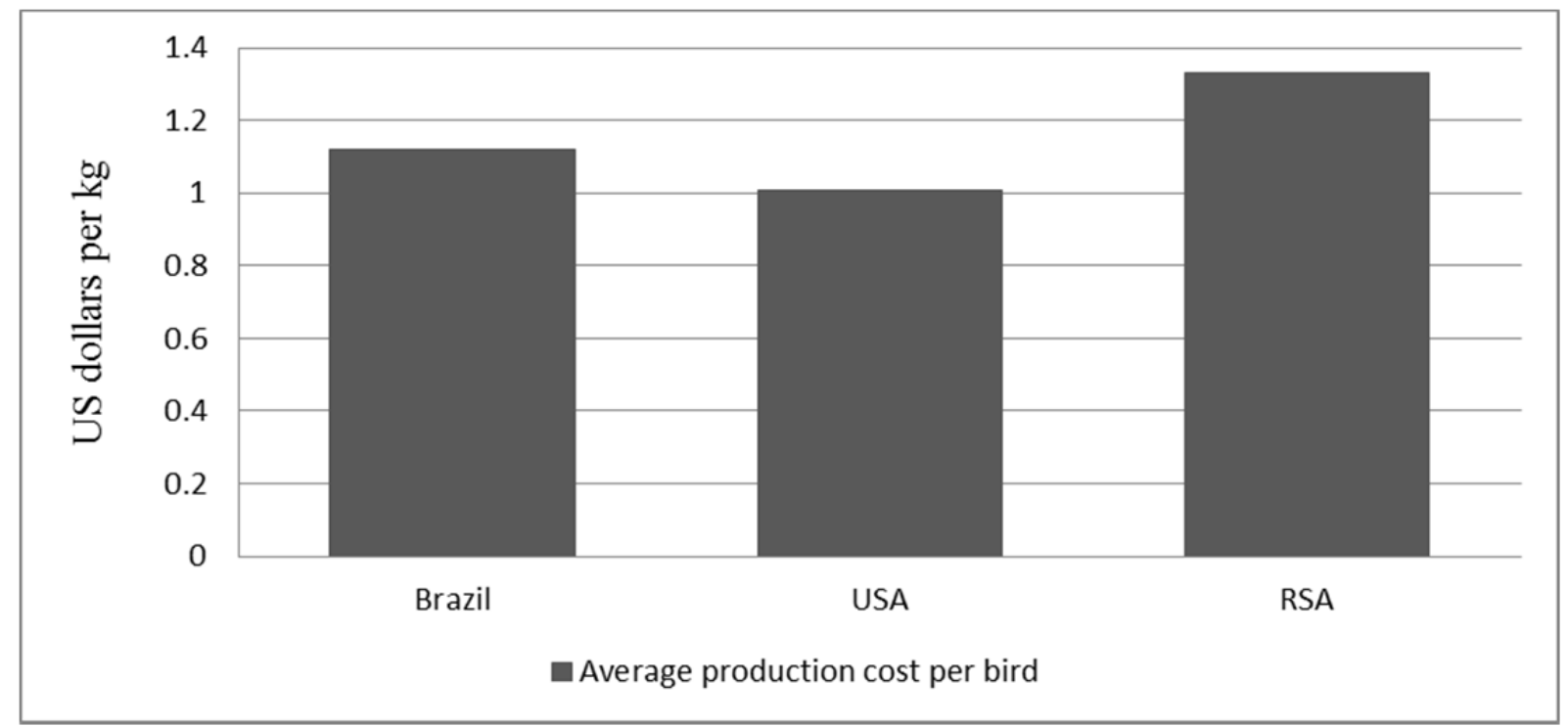

Figure 3: Average production cost per $\mathrm{kg}$ in Brazil, USA and RSA

Source: United States international trade commission (2012:8.11) and SAPA (2011:21)

The United States international trade commission found that the cost per $\mathrm{kg}$ of producing a live bird in Brazil was between 1.05 and 1.19 US dollars, depending on the production region, while in the USA, production costs per kg live bird was approximately 1.01 US dollars (United States International trade commission, 2012:8.11). In South Africa, SAPA estimate the production cost per $\mathrm{kg}$ live bird to be between 1.28 and 1.38 US dollars. Cost of production in South Africa is clearly higher than in the USA and Brazil. Louw, Schoeman and Geyser (2011:9) also identified the quality, consistency and cost of feed as the major contributing input as one of the major challenges facing South African producers.

However, a more fundamental factor underlying the general costs of feed that influences the competitiveness of the South African broiler producers is the price of soybean cake. Soybean cake contributes approximately $18 \%$ of the total weight of the broiler feed ration. Whereas both the US and Brazil are net exporters of soybean cake, South Africa is a net importer with the local crushing industry only now starting to increase capacity to produce more soybean cake locally. This implies that whereas the soybean cake price trades at export parity levels in Brazil and the US, the South African soybean cake price trades at import parity levels. Figure 4 compares the South African soybean cake price to the Brazilian price in dollar terms. From the figure it is evident that South African prices are significantly higher, especially in the last few years. 


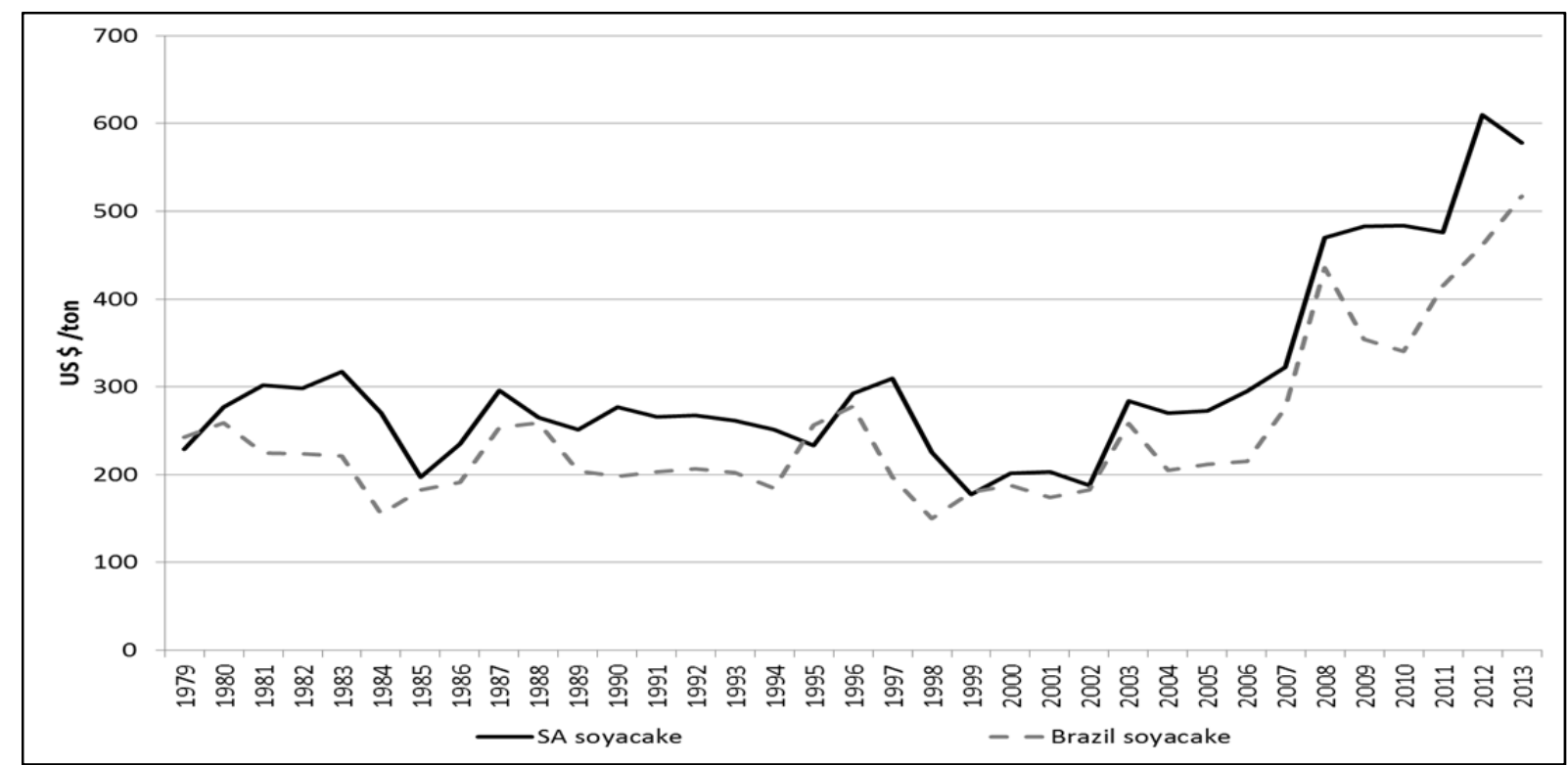

Figure 4: Soybean cake price comparison, South Africa vs the Brazilian price Source: BFAP (2013:131)

\subsection{AN HISTORIC PERSPECTIVE ON BROILER IMPORTS}

South Africa has been a net importer of chicken since markets were liberalised, but it is after the financial crisis in 2009 that imports have reached concerning levels. With single exceptions, imports have remained below 200 thousand tons per annum prior to 2009. In the past three years however, imports have increased from 200 thousand tons in 2009, to 380 thousand tons in 2012 - an increase of $90 \%$. Though imports contributed only $20.39 \%$ of domestic consumption in 2012, giving it the third largest market share behind the two biggest companies in South Africa, it is the effect of imports on price that is a greater concern for the continued sustainability of the industry. South African imports of broiler meat are indicated in Figure 5.

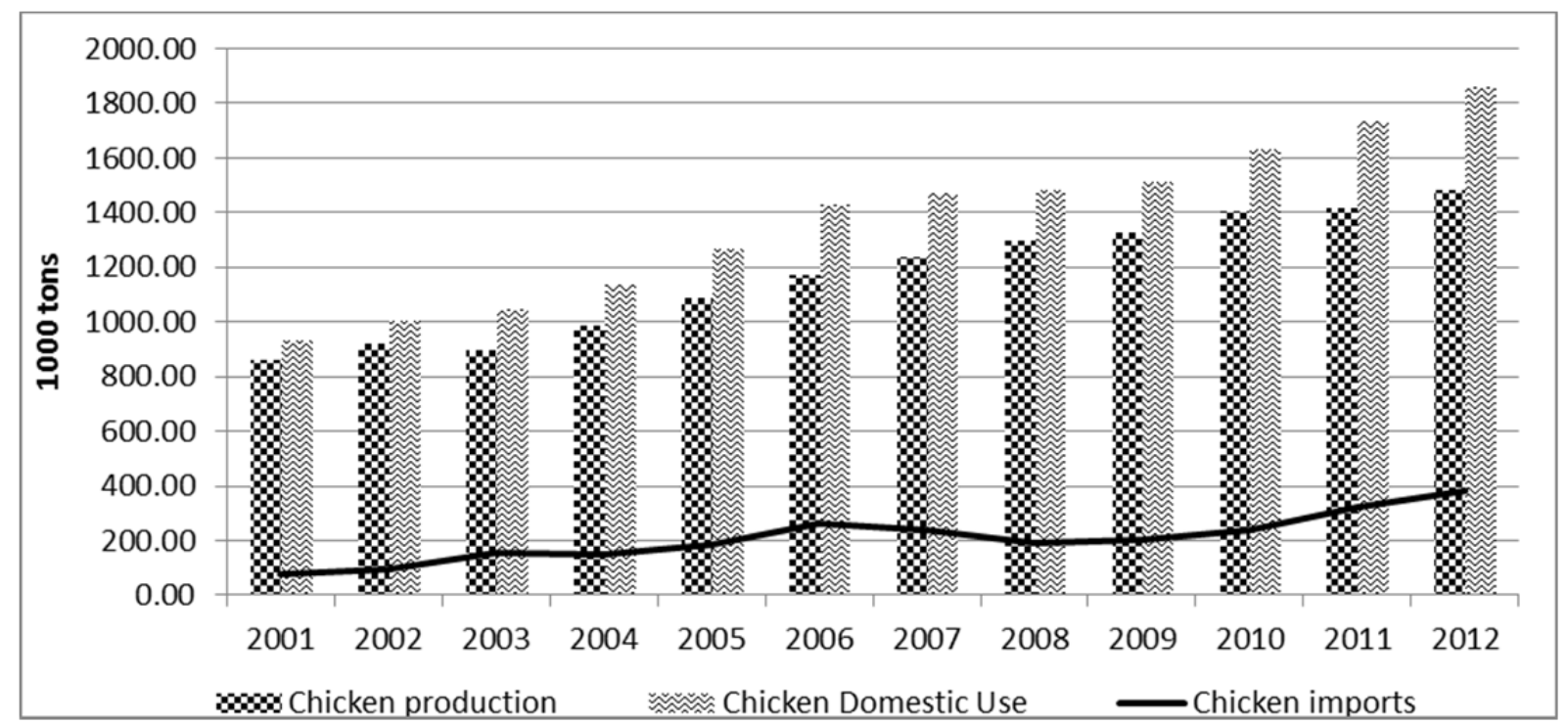

Figure 5: Chicken production, consumption and imports 2001-2012

Source: SAPA (2012:6), South African Revenue Service (SARS) statistics (2012) and BFAP statistics 
Of great concern when considering Figure 5 is that an increase of $13.89 \%$ (226 838 tons) in consumption from 2010 to 2012 was only accompanied by a $5.5 \%$ (77 649 tons) increase in production, with imports providing the balance of chicken consumed. Chicken imports into South Africa are classified by the Harmonised System classification codes, with eight different tariff codes currently in use. The only significant imports however are frozen chicken, which is split into six different classifications. The different classifications of chicken imported to South Africa, as well as the current tariffs are indicated in Table 2. Imports originating from the European Union however are duty free, due to trade agreements currently in place.

Table 2: Classification of chicken meat imports to South Africa

\begin{tabular}{|l|l|c|}
\hline Classification Code & \multicolumn{1}{|c|}{ Description } & Tariff \\
\hline 02071100 & Fowls, not cut in pieces: fresh or chilled & 0 \\
\hline 02071210 & Fowls, not cut in pieces, frozen: mechanically deboned meat & 0 \\
\hline 02071220 & Fowls, not cut in pieces, frozen: carcasses & $27 \%$ \\
\hline 02071290 & Fowls, not cut in pieces, frozen: other & $27 \%$ \\
\hline 02071300 & Fowls, cuts and offal, fresh or chilled & 0 \\
\hline 02071410 & Fowls, cuts and offal, frozen: boneless cuts & $5 \%$ \\
\hline 02071420 & Fowls, cuts and offal, frozen: offal & $27 \%$ \\
\hline 02071490 & Fowls, cuts and offal, frozen: other (includes bone-in portions) & $220 \mathrm{c} / \mathrm{kg}$ \\
\hline
\end{tabular}

Source: SARS (2013:8)

The tariff classification that experienced the greatest increase in imports over the past three years was bone-in portions (02071490), with a 112\% increase from 2010 to 2012. The composition of South Africa's chicken imports according to these tariff classifications are indicated in Figure 6.

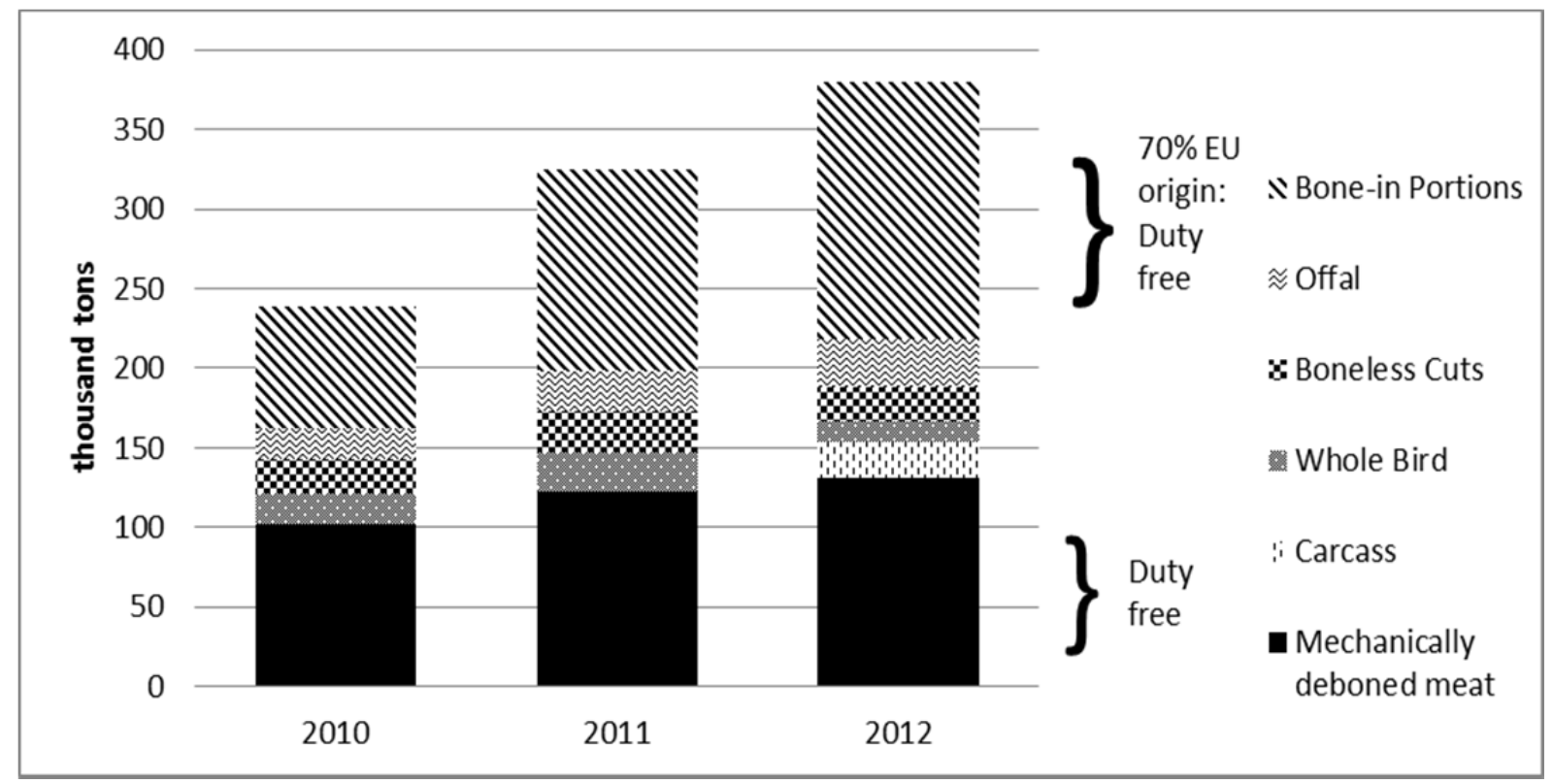

Figure 6: Composition of South Africa's chicken imports per tariff classification

Source: SARS statistics (2013) 
Historically, imports have originated from Brazil and Argentina, who have a strong comparative advantage in producing chicken due to relatively cheaper feed production costs and their status as net exporters of maize and soya cake. In the past two years however, the European Union (EU) has come to the fore as a major player when the origin of imported chicken is concerned. The change in market share of partnering countries in the origin of South African imports is indicated in Figure 7. Due to a change in import tariff classification codes in 2009, the composition of imports is shown only for 2010 to 2012.

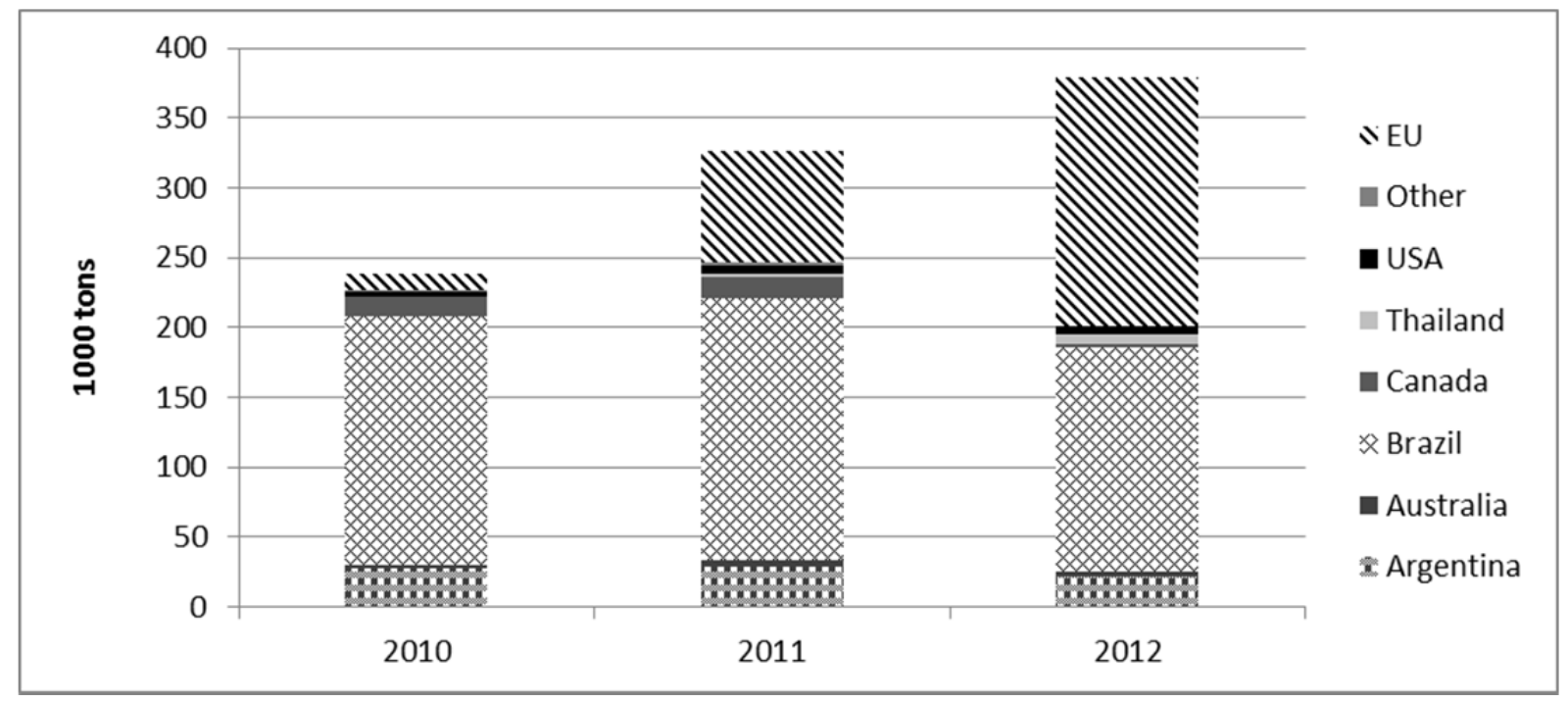

Figure 7: Origin of South African chicken imports: 2010-2012

Source: South African Revenue Service statistics (2013)

While Brazil was the origin of $75 \%$ of South African imports in 2010 , only $40 \%$ of imports originated in Brazil in 2012. The share of imports originating from the EU has increased from $5 \%$ in 2010 to $46.95 \%$ in 2012. This represents an increase from 12290 tons in 2010 to 137 510 tons in 2012. The change in patterns concerning the country of origin is of great importance, as imports from the EU do not carry a tariff. As such, an increase in the general rate of duty will not affect the portion of total imports originating in the EU. With imports originating from the EU not being affected by the application for higher tariffs, strict implementation of rules of origin would be necessary in order to insure that goods imported under the free trade agreement with the EU are produced in the EU.

The fact that Brazil have a clear comparative advantage in the production of chicken would suggest that South Africans would be better off if chicken meat is imported from Brazil, but the fact that broiler production is such a crucial industry within the agricultural sector as well as its role in providing food security has been offered as justification to protect the industry. This would insure greater levels of self-sufficiency for an industry that provides the cheapest form of protein available to South African consumers, while employing 48118 people directly and 59739 people indirectly through support industries (Lovell, 2012:10). 


\section{THEORETICAL EFFECTS OF TRADE PROTECTION}

When considering the support of a critical industry such as the South African broiler industry, various policy options are available to government. These options include tariffs, quotas, price support and deficiency payments (Houck, 1987:45). Due to the fact that tariffs have been the chosen form of support within the South African broiler industry in the past, as well as the fact that the analysis focusses on the effect of increased tariffs as applied for by SAPA, the focus of this section will be on the effect of tariffs alone, excluding other forms of protection.

The chosen form of analysis when considering the effect of protective policy has been partial equilibrium analysis. Within the partial equilibrium setting, the effect of policies on production, consumption and trade is considered for a specific sector, keeping other influences constant. Partial equilibrium analysis has clear advantages in that it keeps the analysis simple, allowing for the effects on an industry to be indicated in a clear, simple manner, sharply indicating the different effects of certain policy decisions. Salvatore (2007:250) further indicates that a partial equilibrium analysis is most appropriate when a small nation imposes a tariff on imports that will not affect world prices. Disadvantages however are that it does not account for substitution effects between commodities (Houck, 1987:29) For the purpose of this analysis, the theoretical concepts are illustrated within this partial equilibrium framework, before an econometric simulation is conducted using a system of equations, where partial equilibrium models from various industries within the South African agricultural sector are linked in order to account for cross substitution effects. Within this closed system of equations, grains are linked to livestock through feed in order to capture the effect of external shocks on the entire sector. The linked system of models can still be described as a partial equilibrium framework, as the entire economy is not included, but rather the agricultural sector.

Traditionally, import tariffs have been important mechanisms used to shield domestic industries from international competition. An import tariff essentially taxes foreign products as they enter the country and as such have the additional effect of generating substantial government revenue (Houck, 1987:45). In order to illustrate the effect of a tariff on social welfare, the effect of applying a tariff must be considered on both the producer and the consumer. The theoretical effect on both producer and consumer surplus of applying a tariff on South African chicken imports is illustrated in Figure 8. 


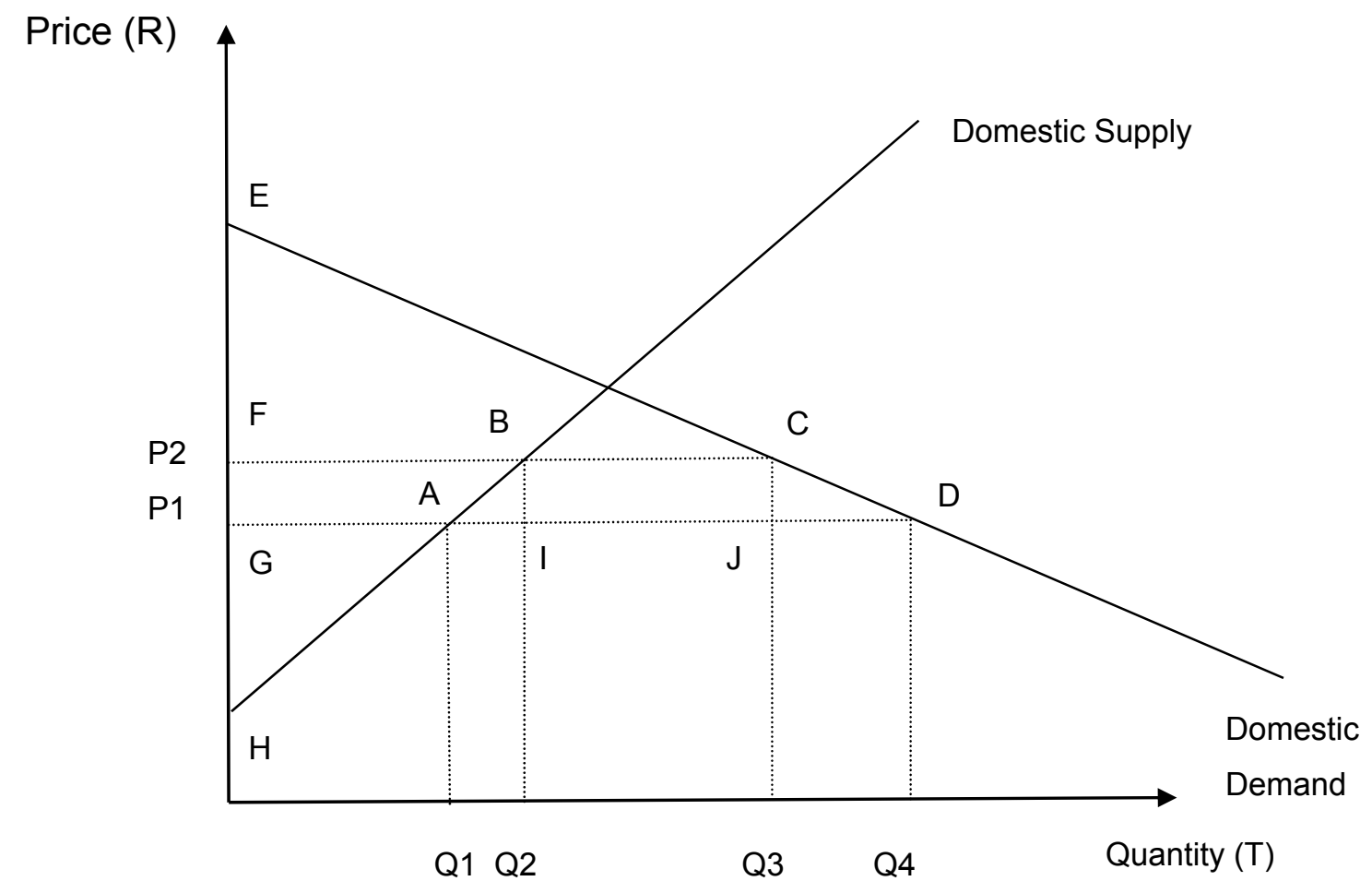

Figure 8: Effect of a tariff increase on South African chicken imports

Source: Adapted from Salvatore (2007:251)

Without the proposed interventions, the South African broiler industry can be described as follows:

At a price of $\mathrm{P} 1$, domestic consumption is $\mathrm{Q} 4$, of which Q1 is produced domestically and the difference between Q4 and Q1 is imported. Producer surplus can be illustrated as triangle $\mathrm{GAH}$, while consumer surplus can be illustrated as triangle EGD. If tariffs were to increase, the price would move to P2, while domestic use would decrease to Q3, of which Q2 would be produced domestically and the difference between Q3 and Q2 would be imported. Producer surplus can now be illustrated by triangle HFB, leading to a gain in consumer surplus of area FBAG. Consumer surplus can now be indicated as triangle EFC, a decrease of area FCDG. This would lead to a net loss to society of area $A B C D$. While the area represented by rectangle IBCJ will be gained in the form of government revenue resulting from the tariff, triangle $\mathrm{ABJ}$ and triangle $\mathrm{ACD}$ will be a net loss to society as a result of the tariff.

From Figure 8, it is clear that producers will gain from the tariff while consumers will lose, however quantification of the amount that producers will gain and consumers will lose depends on the price elasticity of production as well as the price elasticity of consumption. If consumers are more elastic to price changes than producers, as is expected in the chicken industry, then the loss of consumption would be greater than the gain in production. From the theoretical illustration however it follows that regardless of the quantities, producers will be supported at the cost of consumers (Salvatore, 2007:304). 
Economically, supporting producers at the cost of consumers does not make sense, yet tariffs are still used by many countries worldwide, especially in agriculture. Salvatore (2007:304) suggests that as a few producers stand to gain a great deal from protection, they have a strong incentive to lobby for support. On the other hand, since losses will be spread over a much greater number of consumers, each individual consumer would lose much less. As such, consumers are much less likely to organise and oppose tariffs.

When the case of a critical industry is used as justification for support, it can be argued that the importance of the industry to food security in South Africa as well as the need for selfsufficiency would justify support to the industry, even if the support is at the cost of the consumer. In order to make the decision of whether this would be justified however, the benefit to producers as well as the cost to consumers must be quantified. Another matter to consider is which part of the population consumes chicken and whether these consumers are able to bear the cost of supporting the domestic industry.

\section{SIMULATING THE EFFECT OF INCREASED TARIFFS}

An empirical simulation of the effect of different scenarios was done using a set of statistically estimated equations that are structured in a partial equilibrium framework in order to capture the relationship between exogenous and endogenous variables through a wide range of elasticities. The model links grains to livestock through feed and therefore simulates the result of an exogenous shock through different industries in the agricultural sector. Simulating the effect of increased tariffs in this way allows for quantification of changes to the fundamentals of the South African poultry industry, as well as related industries within the sector. Within the system of equations, the chicken producer price is estimated as a function of a weighted average FOB import price with the tariffs for different classifications added on a weighted average basis, the South African beef price as well as the broiler feed price in South Africa.

The simulation involved three scenarios, with different rates of duty for each scenario. Important to note is that for the first two scenarios, imports originating from the EU were not subjected to a tariff due to the trade agreement currently in place. As imports of EU origin are an important component of total imports as illustrated in Figure 7, the third scenario considered the effect of placing the lower tariff scenario on all imports, including those of EU origin. The different scenarios simulated are indicated in Table 3. 
Table3: Tariffs used for baseline and simulated scenarios

\begin{tabular}{|c|c|c|c|c|c|}
\hline HS Code & Description & Baseline & Scenario 1 & Scenario 2 & Scenario 3 \\
\hline 02071100 & $\begin{array}{l}\text { Fowls, not cut in pieces: fresh } \\
\text { or chilled }\end{array}$ & 0 & 0 & 0 & 0 \\
\hline 02071210 & $\begin{array}{l}\text { Fowls, not cut in pieces, frozen: } \\
\text { mechanically deboned meat }\end{array}$ & 0 & 0 & 0 & 0 \\
\hline 02071220 & $\begin{array}{l}\text { Fowls, not cut in pieces, frozen: } \\
\text { carcasses }\end{array}$ & $27 \%$ & $\begin{array}{l}991 \mathrm{c} / \mathrm{kg} \\
\operatorname{Max} 82 \%\end{array}$ & $\begin{array}{l}673 \mathrm{c} / \mathrm{kg} \\
\operatorname{Max} 82 \%\end{array}$ & $\begin{array}{l}673 \mathrm{c} / \mathrm{kg} \\
\operatorname{Max} 82 \%\end{array}$ \\
\hline 02071220 & $\begin{array}{l}\text { Fowls, not cut in pieces, frozen: } \\
\text { carcasses: EU origin }\end{array}$ & 0 & 0 & 0 & $\begin{array}{l}673 \mathrm{c} / \mathrm{kg} \\
\operatorname{Max} 82 \%\end{array}$ \\
\hline 02071290 & $\begin{array}{l}\text { Fowls, not cut in pieces, frozen: } \\
\text { other }\end{array}$ & $27 \%$ & $\begin{array}{l}1111 \mathrm{c} / \mathrm{kg} \\
\operatorname{Max} 82 \%\end{array}$ & $\begin{array}{l}1017 \mathrm{c} / \mathrm{kg} \\
\operatorname{Max} 82 \%\end{array}$ & $\begin{array}{l}1017 \mathrm{c} / \mathrm{kg} \\
\operatorname{Max} 82 \%\end{array}$ \\
\hline 02071290 & $\begin{array}{l}\text { Fowls, not cut in pieces, frozen: } \\
\text { other: EU origin }\end{array}$ & 0 & 0 & 0 & $\begin{array}{l}1017 \mathrm{c} / \mathrm{kg} \\
\operatorname{Max} 82 \%\end{array}$ \\
\hline 02071300 & $\begin{array}{l}\text { Fowls, cuts and offal, fresh or } \\
\text { chilled }\end{array}$ & 0 & 0 & 0 & 0 \\
\hline 02071410 & $\begin{array}{l}\text { Fowls, cuts and offal, frozen: } \\
\text { boneless cuts }\end{array}$ & $5 \%$ & $\begin{array}{l}12 \% \quad \text { or } \\
220 \mathrm{c} / \mathrm{kg}, \\
\operatorname{Max} 82 \%\end{array}$ & $\begin{array}{l}11.5 \% \quad \text { or } \\
217 \mathrm{c} / \mathrm{kg}, \\
\operatorname{Max} 82 \%\end{array}$ & $\begin{array}{l}11.5 \% \quad \text { or } \\
217 \mathrm{c} / \mathrm{kg}, \\
\operatorname{Max} 82 \%\end{array}$ \\
\hline 02071410 & $\begin{array}{l}\text { Fowls, cuts and offal, frozen: } \\
\text { boneless cuts: EU origin }\end{array}$ & 0 & 0 & 0 & $\begin{array}{l}11.5 \% \quad \text { or } \\
217 \mathrm{c} / \mathrm{kg}, \\
\operatorname{Max} 82 \%\end{array}$ \\
\hline 02071420 & $\begin{array}{l}\text { Fowls, cuts and offal, frozen: } \\
\text { offal }\end{array}$ & $27 \%$ & $\begin{array}{l}67 \% \quad \text { or } \\
335 \mathrm{c} / \mathrm{kg}, \\
\operatorname{Max} 82 \%\end{array}$ & $\begin{array}{l}51 \% \quad \text { or } \\
170 \mathrm{c} / \mathrm{kg}, \\
\operatorname{Max} 82 \%\end{array}$ & $\begin{array}{l}51 \% \quad \text { or } \\
170 \mathrm{c} / \mathrm{kg}, \\
\operatorname{Max} 82 \%\end{array}$ \\
\hline 02071420 & $\begin{array}{l}\text { Fowls, cuts and offal, frozen: } \\
\text { offal: EU origin }\end{array}$ & 0 & 0 & 0 & $\begin{array}{ll}51 \% \quad \text { or } \\
170 \mathrm{c} / \mathrm{kg}, \\
\operatorname{Max} 82 \%\end{array}$ \\
\hline 02071490 & $\begin{array}{l}\text { Fowls, cuts and offal, frozen: } \\
\text { other (includes bone-in } \\
\text { portions) }\end{array}$ & $220 \mathrm{c} / \mathrm{kg}$ & $\begin{array}{l}56 \% \quad \text { or } \\
653 \mathrm{c} / \mathrm{kg}, \\
\operatorname{Max} 82 \%\end{array}$ & $\begin{array}{ll}38 \% & \text { or } \\
445 \mathrm{c} / \mathrm{kg}, & \\
\operatorname{Max} 82 \% & \end{array}$ & $\begin{array}{l}38 \% \text { or } \\
445 \mathrm{c} / \mathrm{kg}, \\
\text { Max } 82 \%\end{array}$ \\
\hline 02071490 & $\begin{array}{l}\text { Fowls, cuts and offal, frozen: } \\
\text { other (includes bone-in } \\
\text { portions): EU origin }\end{array}$ & 0 & 0 & 0 & $\begin{array}{l}38 \% \quad \text { or } \\
445 \mathrm{c} / \mathrm{kg}, \\
\operatorname{Max} 82 \%\end{array}$ \\
\hline
\end{tabular}

Where multiple tariff options are presented, the greater of the 2 options is chosen, however all tariffs are capped at the bound rate of $82 \%$. Figure 9 and 10 illustrate the effect of the different tariff scenarios on the chicken price in South Africa. The most extreme scenario (scenario 3) resulted in a 9.4\% increase in the chicken price in 2013, with a long run increase of $8 \%$ in the chicken price. Figure 10 indicates the percentage change in producer price for the 3 different scenarios. 


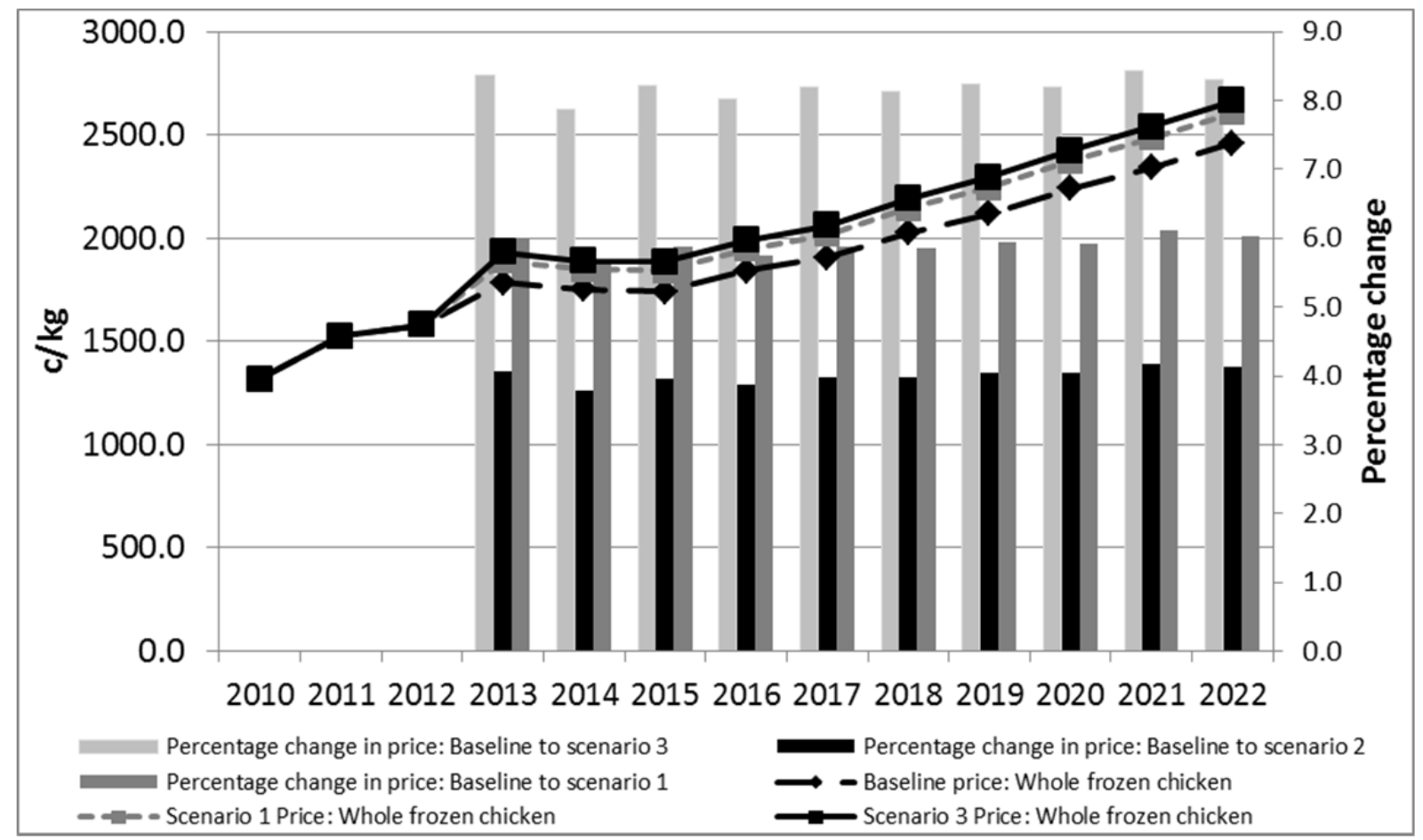

Figure 9: Chicken price comparison: Baseline vs Scenarios

The changes to production, domestic consumption and imports are illustrated in Table 4. Scenario 1 results in an increase of 7.1 thousand tons in 2013, 11.61 thousand tons in 2014 and a long run average increase in production of 19.92 thousand tons. Under the same scenario, domestic use is projected to decrease by 10.76 thousand tons in 2013 , with a long run decrease of 10.05 thousand tons. Imports under the same scenario would decrease by 17.6 thousand tons in 2013, with a long run average decrease of 29.29 thousand tons, which is a $6 \%$ decrease.

Important to note is that the tariff on fresh chicken imports as well as mechanically deboned meat remains 0 across all scenarios. The inclusion of tariffs on imports of EU origin in scenario 3 clearly illustrates the greater effect achieved by applying the tariff to total imports. Though the tariffs are smaller than in scenario 1, the effect on price and as a result production and consumption is greatly increased. When considering 2012 import composition, excluding imports from EU origin results in 70\% of total imports into South Africa in 2012 not being affected by the tariffs proposed by SAPA. As a result, the 17.60 thousand ton decrease in imports for 2013 simulated in scenario 1 could be expressed as a $15.49 \%$ decrease in imports of the tariff lines that will be affected by the proposed tariffs. The inclusion of tariffs on imports of EU origin in scenario 3 clearly illustrates the greater effect achieved by applying the tariff to total imports. Though the tariffs are smaller than in scenario 1, the effect on price and as a result production and consumption is greatly increased. 
Table 4: Summarizing the effect of different tariff scenarios on the fundamentals of the South African broiler industry

\begin{tabular}{|c|c|c|c|c|c|c|c|c|c|c|c|c|c|}
\hline & \multirow{2}{*}{$\begin{array}{r}2012 \\
\text { Current }\end{array}$} & \multicolumn{4}{|c|}{2013} & \multicolumn{4}{|c|}{2014} & \multicolumn{4}{|c|}{ AVG 2015-2020 } \\
\hline & & Baseline & Scenario 1 & Scenario 2 & Scenario 3 & Baseline & Scenario 1 & Scenario 2 & Scenario 3 & Baseline & Scenario 1 & Scenario 2 & Scenario 3 \\
\hline Production (1000 tons) & 1487.83 & 1494.14 & 1501.24 & 1498.97 & 1504.06 & 1519.04 & 1530.64 & 1526.88 & 1535.27 & 1564.61 & 1584.53 & 1578.10 & 1592.39 \\
\hline $\begin{array}{l}\text { Absolute change from } \\
\text { baseline }\end{array}$ & & & 7.10 & 4.83 & 9.91 & & 11.61 & 7.85 & 16.23 & & 19.92 & 13.49 & 27.78 \\
\hline$\%$ change from baseline & & & $0.48 \%$ & $0.32 \%$ & $0.66 \%$ & & $0.76 \%$ & $0.52 \%$ & $1.07 \%$ & & $1.27 \%$ & $0.86 \%$ & $1.78 \%$ \\
\hline Domestic Use (1000 tons) & 1861.40 & 1864.57 & 1853.81 & 1857.24 & 1849.57 & 1992.81 & 1983.10 & 1986.26 & 1979.25 & 2249.94 & 2239.89 & 2243.09 & 2236.04 \\
\hline $\begin{array}{l}\text { Absolute change from } \\
\text { baseline }\end{array}$ & & & -10.76 & -7.32 & -14.99 & & -9.71 & -6.55 & -13.56 & & -10.05 & -6.85 & -13.90 \\
\hline$\%$ change from baseline & & & $-0.58 \%$ & $-0.39 \%$ & $-0.80 \%$ & & $-0.49 \%$ & $-0.33 \%$ & $-0.68 \%$ & & $-0.45 \%$ & $-0.30 \%$ & $-0.62 \%$ \\
\hline Imports (1000 tons) & 380.99 & 378.77 & 361.18 & 366.75 & 354.32 & 482.12 & 460.80 & 467.73 & 452.32 & 693.68 & 663.70 & 673.34 & 651.99 \\
\hline $\begin{array}{l}\text { Absolute change from } \\
\text { baseline }\end{array}$ & & & -17.60 & -12.02 & -24.46 & & -21.32 & -14.40 & -29.81 & & -29.97 & -20.34 & -41.68 \\
\hline$\%$ change from baseline & & & $-4.65 \%$ & $-3.17 \%$ & $-6.46 \%$ & & $-4.42 \%$ & $-2.99 \%$ & $-6.18 \%$ & & $-4.32 \%$ & $-2.93 \%$ & $-6.01 \%$ \\
\hline
\end{tabular}


Apart from the effects on the domestic broiler industry, increased tariffs will also affect other industries, such as maize and soya, through broiler feed. The scenario applied for by SAPA (scenario 1) results in an increase of $0.32 \%$ in maize as feed consumption in 2013, with an average increase of around $0.69 \%$ in the long run. This amounts to 14.7 thousand tons in 2013 and a long run average of 40.7 thousand tons. Including EU imports in scenario 3 results in an increase of $0.44 \%$ in maize as feed consumption in 2013 , with an average increase of around $0.96 \%$ in the long run. This amounts to 20.6 thousand tons in 2013 and a long run average of 56.7 thousand tons.

Industries that produce meat in competition to chicken are also affected by the increase in the domestic chicken price. Scenario 1 resulted in an increase of $2.24 \%$ in the beef price in 2013 , as well as a $2.81 \%$ increase in the pork price in 2013 . The long run average increase in the beef and pork price $1.59 \%$ and $1.97 \%$ respectively under scenario 1 .

An opportunity for employment creation due to increased production in both the poultry and related feed industries is another factor that should considered. According to Lovell (2012:10), the poultry industry employs approximately 48118 employees in primary and secondary production, excluding the primary producers of their raw feed component (Maize and Soybeans producers). Given the fact that poultry is not a labour intensive industry, and the relatively small increase in production resulting from the proposed tariffs, implementation of the proposed tariffs will not lead to large scale job creation. In the context of this analysis however, increased job creation is not the only consideration, as considerable job losses could be experienced if the industry is not competitive over the long run.

\section{AN HISTORIC PERSPECTIVE ON CHICKEN CONSUMPTION IN SOUTH AFRICA}

The effect of increased import tariffs on the profitability and therefore long run sustainability of producers is clearly positive, as described in section 4 , but in order to provide a balanced perspective of the effect on social welfare, the position of the consumer should also be considered.

As the cheapest source of animal protein in South Africa, chicken is also dominant when comparing consumption of different meat products. Of total meat consumed in South Africa in 2011, 55\% was chicken. As per capita income has increased over time, chicken consumption has outpaced consumption growth in all other meat products, increasing its share in total meat consumption on a continuous basis. The composition of meat consumption in South Africa is illustrated in Figure 10. 


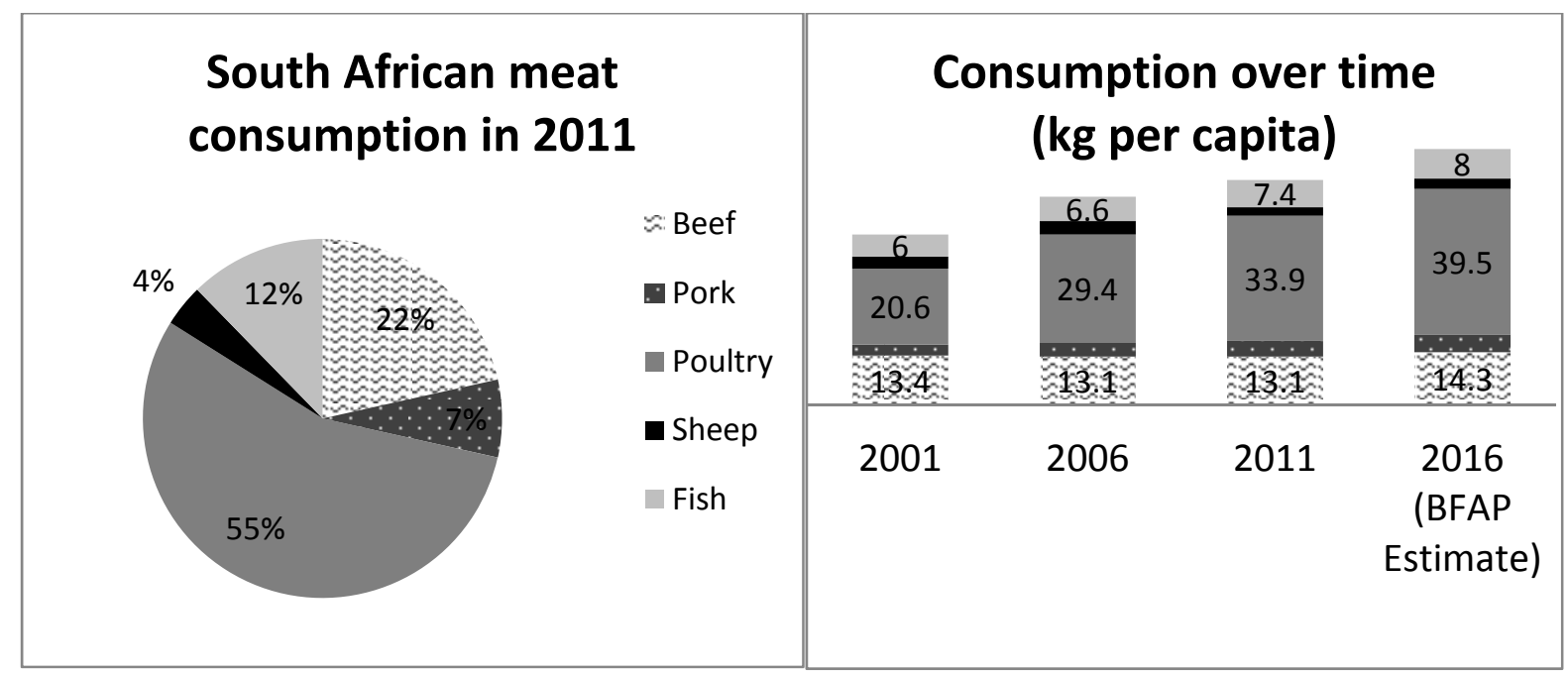

Figure 10: Meat consumption pattern in South Africa

Source: DAFF, FAO and BFAP (2013) statistics

Chicken is popular not only due to the price, but also due to the fact that it is healthy and convenient. Due to its status as the cheapest source of animal protein available, aggregate national chicken consumption is inelastic to changes in price, mainly due to a lack of alternatives. Disaggregation of chicken consumption based on household income yields further interesting results, as indicated in Figure 11. Total expenditure on chicken is disaggregated at household level, based on total household income, giving an indication of the total value of chicken bought by poor, middle class and wealthy consumers. From figure $6,28.25 \%$ of the total value of chicken bought was by the highest earning quintile (average expenditure of R124175.50 per annum) in 2010, while $9.13 \%$ of the total value was spent by consumers in the lowest earning quintile (average expenditure of R4208.56 per annum). Considering the value spent in isolation can be misleading regarding quantities, as the value per $\mathrm{kg}$ chicken is likely to be greater at higher income levels, but the lack of statistics regarding volume consumed makes value the only available indication of consumption at various income groups.

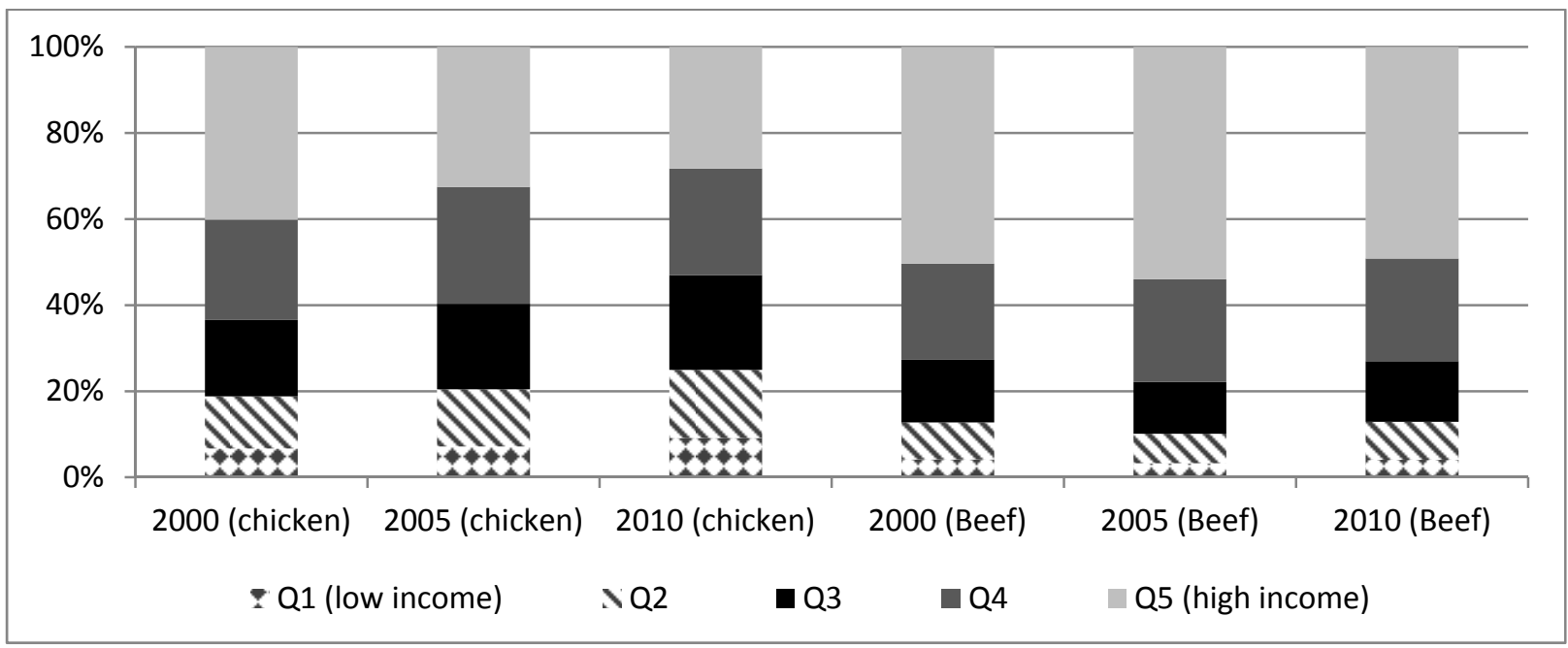

Figure 11: Chicken and Beef consumption per income quintile: 2000-2010

Source: Stats SA (2012) 
Of the total value of chicken consumed in 2010, 46.98\% was by households earning less than R50 000 per annum (Quintile 1-3). Despite the lack of alternatives, these consumers may be more elastic to price changes than the consumers in quintile 4 and 5 , simply due to unaffordability if the price goes up. As consumers in quintile 1 spend $34.75 \%$ of total expenditure on food (of which $12.72 \%$ is spent on chicken), the effect of an increase in the price of chicken will be the greatest for this group. When considering beef as a more expensive alternative, $49.17 \%$ of the total value spent on beef is by consumers in the $5^{\text {th }}$ quintile that earn the most. In order to illustrate the importance of chicken as protein source to lower income groups, the composition of the food consumption basket at household level in 2010 is illustrated in Figure 12.

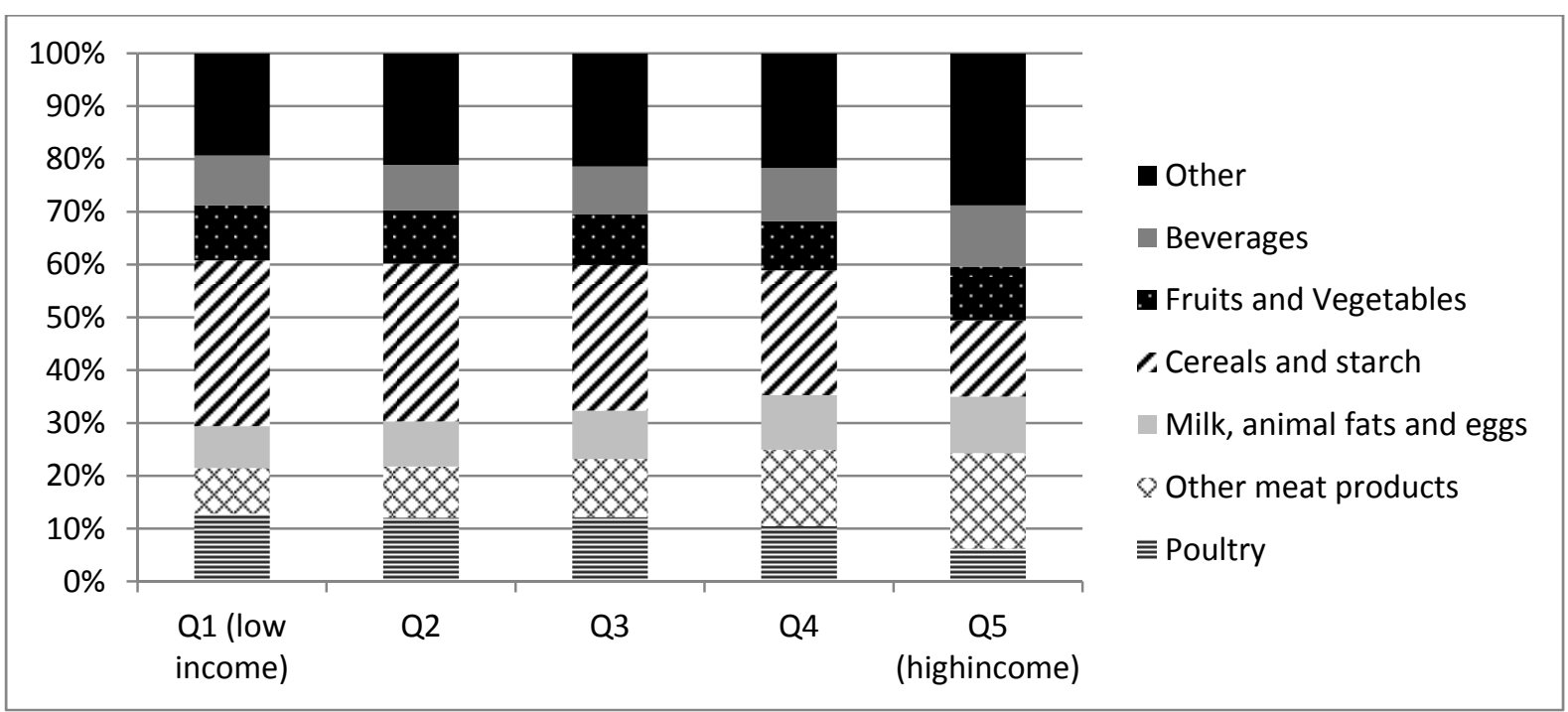

Figure 12: Poultry as percentage of food consumption basket in 2010

Source: Stats SA (2012)

When considering the effect of the proposed tariffs on the consumer however, the producer price is only important considering its effect on the retail price, which remains the ultimate consideration as the price that consumers must pay. The effect of the proposed tariff on retail prices is analysed in the next section.

\section{QUANTIFYING THE EFFECT OF PROPOSED TARRIFFS ON RETAIL PRICES}

In order to quantify the effect of the proposed tariffs on the retail price, an error correction model was estimated based on monthly data from January 2007 to December 2012. The purpose of the estimation is to determine the extent to which changes in producer prices are transmitted to retail level and the estimation essentially involves three steps. Firstly, a cointegration equation is estimated in order to test for a long run co-integrating relationship between the real broiler producer price and the real chicken retail price. The theoretical function can be conceptualised as follows:

$$
\text { RCRETPSA }=\alpha+\beta_{1} R B P P S A+\mu
$$


Where:

RCRETPSA is real retail prices

$R B P P S A$ is real producer prices

$\mu$ is the associated error term.

The estimation output for the long run co-integration equation is presented in Table 5. The dependant variable is the real retail price of chicken.

Table 5: Estimation results of the co-integration equation

\begin{tabular}{|c|l|l|l|}
\hline Variable & Coefficient & Elasticity & T-statistic \\
\hline Real broiler producer price & 1.08 & 0.62 & $10.70^{* * *}$ \\
\hline
\end{tabular}

Significance level: $* * * 1 \%, * * 5 \%$ and $* 10 \%$

The calculated elasticity of 0.62 indicates that a $10 \%$ increase in the real broiler producer price would lead to a $6.2 \%$ increase in the real retail price of chicken. This value is however not definitive, as it will be adjusted in an Engle-Yoo third step to account for bias following the estimation of the ECM.

Meaningful statistical evaluation of the co-integration equation includes an Engle-Granger co-integration test, performed in order to test for the existence of a long run co-integrating relationship between the real broiler producer price and the real retail price of chicken. The results of the co-integration test are presented in Table 6. As the residual series is stationary, it is concluded that a significant long run co-integrating relationship exists between the real broiler producer price and the real retail price of chicken.

Table 6: Results of the Engle-Granger co-integration test

\begin{tabular}{|c|c|c|c|c|}
\hline Series & Null Hypothesis & Model & ADF & Conclusion \\
\hline \multirow{3}{*}{$\begin{array}{l}\text { Residual of the } \\
\text { co-integration } \\
\text { equation }\end{array}$} & \multirow{3}{*}{$\begin{array}{l}\text { Residual series has a } \\
\text { unit root }\end{array}$} & Intercept & $-3.93 * * *$ & \multirow{3}{*}{$\begin{array}{l}\text { Residual } \\
\text { series does } \\
\text { not have a } \\
\text { unit root }\end{array}$} \\
\hline & & Trend and Intercept & $-4.77 * * *$ & \\
\hline & & None & $-3.97 * * *$ & \\
\hline
\end{tabular}

Significance level: $* * * 1 \%, * * 5 \%$ and $* 10 \%$

The second step is the estimation of an ECM to account for the short run variations around the long run relationship. The following is a generic representation of the model to be estimated:

$$
\Delta R C R E T P S A_{t}=\alpha+\beta_{1} \Delta R B P P S A_{t-i}+\theta E C_{t-1}+\varepsilon_{t}
$$


Where:

$\triangle R C R E T P S A_{t}$ is poultry retail prices in first difference form

$\triangle R B P P S A_{t}$ is poultry producer prices in first difference form

$E C_{t-1}$ is the error correction term

$\varepsilon_{t}$ is the associated error term

The estimation results of the ECM are presented in Table 7. The dependant variable is the real retail price of chicken in first differenced form, in order to render it stationary.

Table 7: Estimation results of the ECM

\begin{tabular}{|l|c|c|}
\hline \multicolumn{1}{|c|}{ Variable } & Coefficient & P-Value \\
\hline D(real broiler producer price) & 0.4249 & $0.0051^{* * *}$ \\
\hline EC(-1) & -0.2925 & $0.0004^{* * *}$ \\
\hline
\end{tabular}

Significance level: $* * * 1 \%, * * 5 \%$ and $* 10 \%$

The coefficient of the error correction term measures the rate at which the system returns to equilibrium following a shock to the producer price. In this instance, the value of -0.29 indicates that $29 \%$ of the disequilibrium will be corrected in a single period, hence a shock to the producer price would require 3.45 months in order to transmit through the value chain, before prices return to equilibrium levels. The fact that the coefficient on the error correction term is negative is an indication that the model converges back to equilibrium. Both the real broiler producer price and the error correction term are statistically significant variables at a $1 \%$ level of significance. The F-statistic of 9.59 validates the overall significance of the ECM, while the goodness of fit remains low with an adjusted $\mathrm{R}^{2}$ of 0.2 . Ferris $(2005: 311)$ however indicates that agricultural variables, particularly in differenced form, often leads to very low $\mathrm{R}^{2}$ values, while Paltasingh and Goyari (2013) also found very low r-square values when dealing with agricultural variables in differenced form. Given the significance of the Fstatistic as well as the individual t-statistics, the ECM is maintained in its current form.

In order to adjust the long run parameter and quantify the extent to which producer prices are transmitted to retail prices, the Engle-Yoo third step adjustment is performed on the coefficients of the co-integration equation. In order to make this adjustment, a regression analysis is computed with the residual series of the ECM as dependant variable. The results of the Engle-Yoo third step adjustment are summarised in Table 8.

Table 8: Engle-Yoo third step adjustment

\begin{tabular}{|c|c|}
\hline Variable & Coefficient adjustment \\
\hline $0.292544 *($ real broiler producer price $)$ & $1.079643-0.001380=1.078263$ \\
\hline
\end{tabular}


Following the Engle-Yoo third step adjustment, long run elasticities, as well as the relevant $t$ statistics are illustrated in Table 9. The real broiler producer price remains statistically significant at a $1 \%$ level, while the elasticity of 0.62 indicates that an increase of $10 \%$ in the real broiler producer price will be accompanied by an increase of $6.2 \%$ in the retail price of chicken.

Following the Engle-Yoo adjustment, the estimated elasticities are used to integrate the retail price equation into the partial equilibrium modelling framework. The percentage change in the price for the 3 different scenarios compared to the baseline simulation is illustrated in Figure 13.

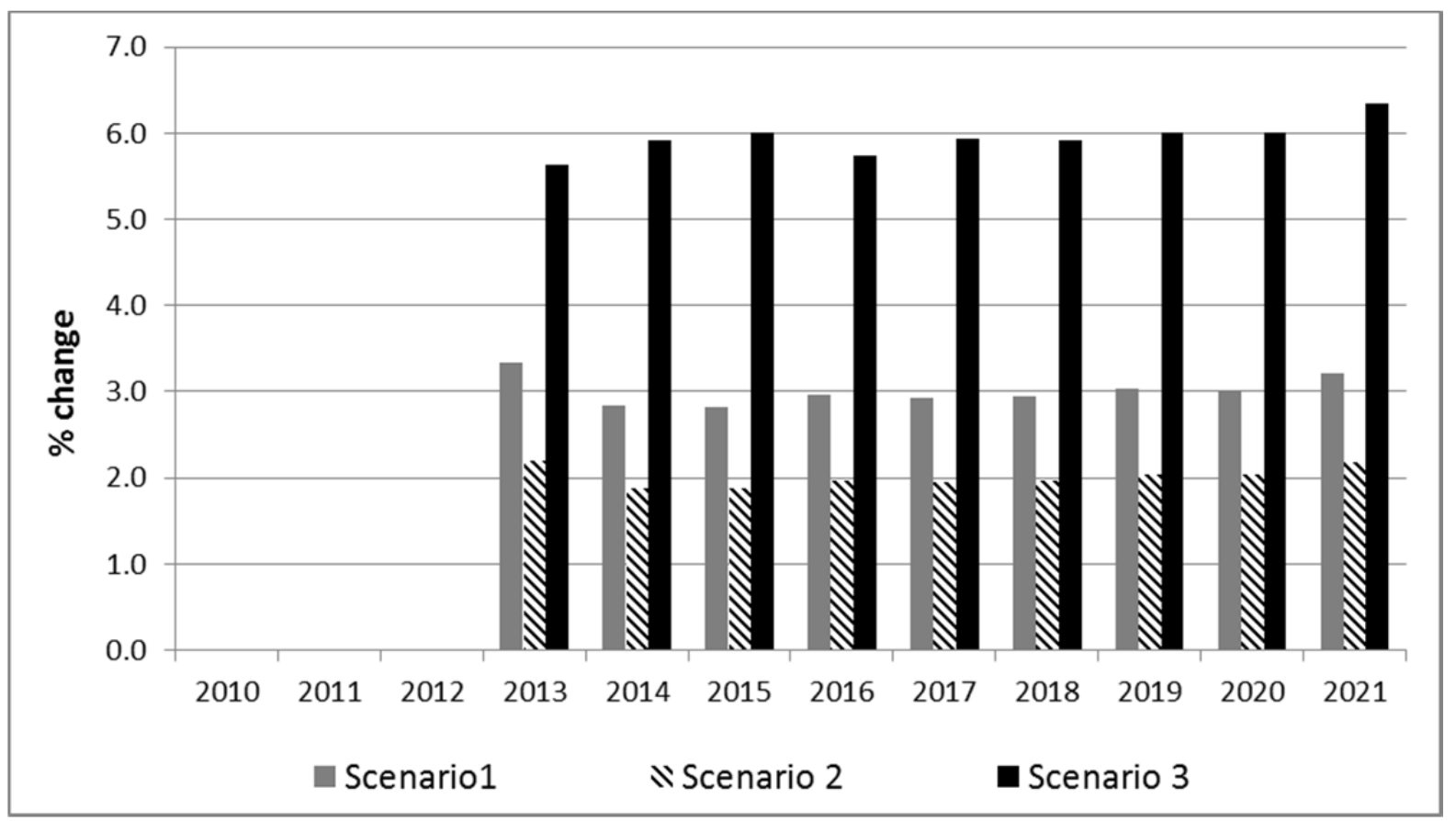

Figure 13: Percentage change in chicken retail price for three different scenarios

\section{CONCLUSION}

Broiler production is a very important industry within South African agriculture, not only due to its substantial contribution to food security in providing the cheapest form of animal protein, but also as one of the largest contributors to agricultural GDP. At times the industry struggles to compete in the international market due to higher feed costs relative to other producing countries and import protection could be warranted based on the importance of the industry. At the same time, increased tariffs will increase the price, adversely affected the poorest segment of South African consumers.

The South African poultry association claims that the tariffs applied for were not designed to close South Africa's borders to imports, but simply to place South African producers on level footing, allowing them to compete with international competitors. From the simulated results, this could be validated, as total chicken imports under scenario 1 decrease by only $4.32 \%$. 
When considering the fact that only $30 \%$ of 2012 imports would be affected by the tariff, the effective decrease of 30 thousand tons amounts to a $14.4 \%$ decrease in the bundle of imports that would be affected by the tariffs in the long run.

When considering the aggregate effect of higher tariffs on both producers and consumers, the positive effect of a $6 \%$ increase in the producer price must be weighed against the negative effect of a $3.4 \%$ increase in the retail price, which is likely to affect the poorest consumers. In deciding whether increased support to producers should be implemented, the key questions to be answered is whether the $6 \%$ increase in the producer price is enough for producers to reinvest and continue producing chicken, while at the same time considering whether South African consumers, specifically consumers with a low income would be able to absorb a $3.4 \%$ increase in the retail price. Mechanically deboned chicken, as used in various processed meats, will not be affected by the increased tariffs and therefore remains as a low cost alternative if an increase in the price of chicken pieces cannot be absorbed by consumers.

Alternative measures or policy interventions could also be considered in order to achieve a balanced outcome between producers need for support and the effect of that support on consumers. The chicken to feed price ratio remains an important indicator of the international competitiveness of the industry and the possibility of a tariff triggered by a specific ratio of international prices to domestic feed prices could be considered. This would minimise the effect on consumers, while supporting producers when necessary. A zero VAT rating on chicken could also achieve a more balanced affect, as producer prices could increase without increasing the retail price, yet the knock-on effects on other meat industries and the drop in government revenue has to be considered. An innovative approach is no doubt necessary to achieve the balanced outcome and ensure the long run sustainability of South Africa's largest agricultural industry. 


\section{REFERENCES}

Bureau for Food and Agricultural Policy. 2013. The South African agricultural baseline 2013. Pretoria: University of Pretoria.

Du Toit, C. 2011. Food Security. South African Department of Agriculture, Forrestry and Fisheries, Directorate Economic Services, Production economics unit. [Online] Available from: http://www.nda.agric.za/docs/GenReports/FoodSecurity.pdf [Downloaded 2013-05$15]$.

Ferris, J. N. 2005. Agricultural prices and commodity market analysis. Michigan: Michigan State University Press.

Food and Agricultural Organisation of the United Nations. 1996. Rome declaration on world food security. [Online] Available at: http://www.fao.org/docrep/003/w3613e/w3613e00.HTM [Accessed 12-06-2013].

Houck, J.P. 1987. Elements of agricultural trade policies. Illinois: Waveland press.

Laroche, D.C. \& Postolle, A. 2011. Food sovereignty and agricultural trade policy commitments: what are the margins of manoeuvre for West African states? Paper prepared for presentation at the European Association of Agricultural Economists (EAAE) Congress, Zurich, Switzerland, 30 August - 2 September, 2011.

Louw, A., Schoeman, J.J. \& Geyser, J.M. 2011 Pork and Broiler industry supply chain study with emphasis on feed and feed-related issues. National Agricultural Marketing Council, South Africa. [Online] Available from http://www.namc.co.za/dnn/PublishedReports/CommodityProductStudies/PerCategory.aspx [Downloaded 2012-05-10].

Lovell, K. 2012. The South African broiler industry and its outlook going forward. [Online] Available from: http://www.afma.co.za/imgs/Mr\%20Kevin\%20Lovell\%20$\% 20$ SA $\% 20$ Poultry $\% 20$ Industry $\% 20$ and $\% 20$ its $\% 20$ outlook $\% 20$ going $\% 20$ forward $\% 20 \% 20$ \%20AFMA\%20AGM\%207\%20September\%202012.pdf [Downloaded 2013-02-20].

Paltasingh, K. R. \& Goyari, P. 2013. Supply response in rain-fed agriculture of Odisha, Eastern India: A vector error correction approach. Agricultural Economics Review 14(2):89104.

Salvatore, D. 2007. International Economics. $9^{\text {th }}$ ed. New Jersey: John Wiley \& Sons. 
South Africa. Department of Agriculture, Forrestry and Fisheries (DAFF). 2010. A profile of the South African broiler market value chain. [Online] Available from:

www.daff.gov.za/docs/AMCP/BroilerMVCP2010-11.pdf [Downloaded: 2012-04-27].

South Africa. Department of Agriculture, Forrestry and Fisheries (DAFF). 2012. Abstract of Agricultural Statistics 2012. [Online] Available from:

http://www.daff.gov.za/docs/statsinfo/Abstract_2012.pdf [Downloaded: 2013-02-21].

Southern African Poultry Association (SAPA). 2011. The South African poultry industry profile for 2010. [Online] Available from:

http://www.sapoultry.co.za/pdf\%20permanent/2011\%20sapa\%20industry\%20profile.pdf [Downloaded: 2012-02-20].

Southern African Poultry Association (SAPA). 2012. SAPA broiler production report for the fourth quarter of 2012. [Online] Available from:

http://www.sapoultry.co.za/pdf\%20quarterly\%20reports/2012\%2012\%20BROILER\%20REP ORT\%20-\%20EXEC.pdf [Downloaded: 2013-05-20].

Southern African Poultry Association (SAPA). 2013. SAPA broiler organisation committee chairperson's report for 2013. [Online] Available from:

http://www.sapoultry.co.za/pdf\%20annualreports/BROILER\%20ORGANISATION\%20REP ORT.pdf [Downloaded: 2014-09-20].

South African Revenue Service. 2013. Schedules to the customs and excise act. [Online] Available from: http://www.sars.gov.za/AllDocs/LegalDoclib/SCEA1964/LAPD-LPrimTariff-2012-04\%20-

\%20Schedule \%20No\%201\%20Part\%201\%20Chapters\%201\%20to\%2099.pdf [Downloaded: 2013-05-04]

Statistics South Africa. 2012. Income and Expenditure of households 2010/11. Statistical release P0100. 6 November. Pretoria: Statistics South Africa.

United States International Trade Commision. 2012. Brazil: Competitive Factors in Brazil Affecting U.S. and Brazilian Agricultural Sales in Selected Third Country Markets Investigation Nr. 332-524. [Online] Available from:

http://www.usitc.gov/publications/332/pub4310.pdf [Downloaded: 2013-02-18].

United States of America. Department of Agriculture Foreign Agricultural Service. 2012. Livestock and poultry: world markets and trade. [Online] Available from http://www.fas.usda.gov/dlp/circular/2012/livestock_0412.pdf [Downloaded: 2012-05-16]. 